\title{
Profesionales de la arquitectura técnica, historia del arte y arqueología en Jaén firman un convenio pionero
}

El pasado mes de febrero se firmó un convenio de colaboración entre los colegios profesionales de Aparejadores y Arquitectos Técnicos de Jaén y el Ilustre Colegio de Doctores y Licenciados en Filosofía y Letras y Ciencias de Granada, Almería y Jaén. Este documento constituye un gran avance porque reconoce un papel central en la tutela a los profesionales de la arqueología y la historia del arte, tal y como se reclamó en el debate que se planteó en la sección Perspectivas de revista ph 85 (abril 2014).

Francisco Javier Ruiz Ramos | vocal por Jaén de la Sección Propia de Historia del Arte del Colegio Oficial de Doctores y Licenciados en Filosofía y Letras y Ciencias de Granada, Almería y Jaén

URL de la contribución <www.iaph.es/revistaph/index.php/revistaph/article/view/3604>

Resulta sorprendente el hecho de que aún la normativa legal existente en materia de patrimonio histórico, tanto de ámbito estatal como para Andalucía, venga a obviar la cualificación de los profesionales de historia del arte en materia de patrimonio histórico.

Como bien sabemos, se trata de un debate y de una reivindicación que, no por vieja, es menos justa y consecuente con el asentamiento de unos valores en la sociedad que, afortunadamente, cada vez son más respetuosos con nuestro patrimonio. Sin embargo sigue fallando cuando no se cuenta con este colectivo de una manera sistemática y su labor no se une indefectiblemente al ámbito patrimonial.

En unos casos porque se obvia, como podemos ver en la Ley 7/2002 de 17 de diciembre de ordenación urbanística de Andalucía (LOUA), dejando toda la responsabilidad en cualquier intervención en manos de los arquitectos; en otros, como la Ley 14/2007 de 29 de noviembre de patrimonio histórico de Andalucía, sigue pendiente la reglamentación en la que se definan los procedimientos y se otorguen las competencias correspondientes en materia profesional.

De esta forma los colectivos arqueológico y de historia del arte, quedan relegados a un incomprensible plano secundario -por no decir una práctica invisibilidad- en este ámbito, recayendo toda la responsabilidad y competencias, salvo casos muy puntuales, en arquitectos y aparejadores. De esta forma, los resultados cuando se trata de intervenciones realizadas en el ámbito del patrimonio histórico y artístico, vienen a resultar muy desiguales $\mathrm{y}$, en muchos casos, se producen auténticos atentados que trascienden la controversia meramente profesional para alcanzar una dimensión social.

Las actuaciones más "vanguardistas" -lo que viene a constituir una loable excepción- optan por proyectos e intervenciones realizadas por equipos multidisciplinares donde, además de arquitectos y arquitectos técnicos, la presencia de historiadores del arte y arqueólogos se está viendo como imprescindible para obtener resultados sobresalientes y verdaderamente respetuosos fundamentados, técnica y metodológicamente, en estas disciplinas cuya solvencia, a todas luces insustituible, está más que contrastada.

En este sentido, el pasado mes de febrero se firmó un convenio de colaboración entre los colegios profesionales de Aparejadores y Arquitectos Técnicos de Jaén y el Ilustre C. de D. y L. en Filosofía y Letras y Ciencias de Granada, Almería y Jaén que constituye un gran avance puesto que, además de sentar las bases para actuaciones formativas comunes en ambos colectivos, los aparejadores se comprometen a conformar equipos donde se incluyan historiadores del arte y arqueólogos, siempre que se produzcan intervenciones en inmuebles de interés, catalogados o no, histórico y/o artístico. Un gran avance, pionero en toda España. 